\title{
Heparan sulfate proteoglycan induces the production of NO and TNF- $\alpha$ by murine microglia
}

Simona Bussini ${ }^{1}$, Lucia Meda ${ }^{1}$, Elio Scarpini ${ }^{1}$, Emilio Clementi², Giancarlo Conti ${ }^{1}$, Marco Tiriticco ${ }^{1}$, Nereo Bresolin ${ }^{1}$ and Pierluigi Baron*1

Address: ${ }^{1}$ Department of Neurological Sciences, Centre for Excellence on Neurodegenerative Diseases and "Dino Ferrari" Center, University of Milan, Fondazione IRCCS "Ospedale Maggiore Policlinico, Mangiagalli e Regina Elena", Via F. Sforza 35, 20122 Milan, Italy and 2Dept. Preclinical Sciences, University of Milano, 20157 - Milano and E.Medea Scientific Institute 23842 - Bosisio Pasini, Italy

Email: Simona Bussini - clinneur@unimi.it; Lucia Meda - clinneur@unimi.it; Elio Scarpini - elio.scarpini@unimi.it; Emilio Clementi - clementi.emilio@ hsr.it; Giancarlo Conti - clinneur@unimi.it; Marco Tiriticco - marco.tiriticco@libero.it; Nereo Bresolin - nereo.bresolin@unimi.it; Pierluigi Baron* - pierluigi.baron@unimi.it

* Corresponding author

Published: 16 July 2005

Immunity \& Ageing 2005, 2:1 I doi:10.1 186/1742-4933-2-II
Received: 22 April 2005

Accepted: 16 July 2005

This article is available from: http://www.immunityageing.com/content/2/I/II

(C) 2005 Bussini et al; licensee BioMed Central Ltd.

This is an Open Access article distributed under the terms of the Creative Commons Attribution License (http://creativecommons.org/licenses/by/2.0), which permits unrestricted use, distribution, and reproduction in any medium, provided the original work is properly cited.

\begin{abstract}
Background: A common feature of Alzheimer's disease (AD) pathology is the abundance of activated microglia in neuritic plaques containing amyloid-beta protein $(A \beta)$ and associated molecules including heparan sulfate proteoglycan (HSPG). Besides the role as pathological chaperone favouring amyloidogenesis, little is known about whether or not HSPG can induce microglial activation. Cultures of primary murine microglia were used to assess the effect of HSPG on production of proinflammatory molecules that are known to be present in neuritic plaques of AD.

Results: HSPG stimulated up-regulation of tumor necrosis factor-alpha (TNF- $\alpha$ ), production of inducible nitric oxide synthase (iNOS) mRNA and accumulation of TNF- $\alpha$ protein and nitrite $\left(\mathrm{NO}_{2}{ }^{-}\right)$in a time- and concentration-dependent manner. The effects of HSPG were primarily due to the property of the protein core as indicated by the lack of microglial accumulation of TNF- $\alpha$ and $\mathrm{NO}_{2}{ }^{-}$in response to denaturated HSPG or heparan sulfate GAG chains (HS).
\end{abstract}

Conclusion: These data demonstrate that HSPG may contribute to chronic microglial activation and neurodegeneration seen in neuritic plaques of $A D$.

\section{Introduction}

Senile plaques in the Alzheimer disease (AD) brain are characterized by the presence of an amyloid core consisting of fibrillar $A \beta$, surrounded by a wreath of dystrophic neurites and activated microglial cells. Reactive microglia release a variety of potentially neurotoxic compounds, including cytokines and free radicals. Many research groups have provided evidence that deposition of aggre- gated $A \beta$ is centrally involved in the chronic inflammatory process occurring in senile plaques of $\mathrm{AD}$ brain $[1,2]$.

$A \beta$ is a 39- to 42-amino-acid peptide that arises from proteolytic processing of the amyloid precursor protein (APP) $[3,4]$. The $A \beta$ peptide that is found in the senile plaques and cerebrovascular deposits exists as a multimeric aggregate with a fibrillar appearance [5]. Several other molecules have also been shown to be associated with $A \beta$ 
deposits, and in vitro studies of fibrillogenesis suggest they may be important in the aggregation and persistence of the $A \beta$ fibrils in vivo. These include apolipoprotein $E$, laminin, acetylcholinesterase, $\alpha_{1}$-antichymotrypsin and heparan sulfate proteoglycan (HSPG) [6-11].

HSPG is a multifunctional macromolecule characterized by a core polypeptide to which glycosaminoglycans (GAGs) are covalently attached. There are at least four different classes of HSPG present in AD, which are either associated with the cell membrane or with the extracellular matrix [12]. HSPG has been consistently associated with both diffuse and neuritic plaques $[13,14]$. Its early presence in $\mathrm{AD}$ pathological alterations as well as its immunohistochemical colocalization with all varieties of $\mathrm{A} \beta$ plaques, irrespective of their stage of maturation, have suggested that HSPG could play an active role in plaque formation. In this regard it has been proposed that HSPG facilitates $A \beta$ deposition and/or promotes $A \beta$ persistence by inhibiting clearance mechanisms, thus augmenting the formation of $A \beta$ deposits in $\mathrm{AD}$ [15]. Consistent with this hypothesis, in vitro studies have shown that HSPG can bind with high affinity to A $\beta$ as well as to APP and it protects $A \beta$ from protease degradation [16-19].

Besides its function in amyloidogenic pathways, HSPG might contribute to AD pathogenesis also through activation of microglial cells. This possibility has never been investigated. To study this we have assessed in "in vitro" cultures of mouse microglial cells, two known markers of their activation, i.e. production of the proinflammatory cytokine tumor necrosis factor- $\alpha$ (TNF- $\alpha$ ) and expression of the mRNA for the inducible nitric oxide (NO) synthase (iNOS). This enzyme is generated in microglia in response to a variety of pro-inflammatory cytokines and bacterial products, such as lipopolysaccharide (LPS). In addition, we have measured in the culture media supernatants the accumulation of $\mathrm{NO}_{2}{ }^{-}$, a good proxy for generation of $\mathrm{NO}$ by iNOS. Our results show that HSPG might contribute to neurodegeneration in neuritic plaques of $\mathrm{AD}$ also through activation of microglial cells and the ensuing increased inflammatory response.

\section{Materials and methods \\ Reagents}

Heparan sulfate proteoglycan (HSPG), heparan sulfate (HS), lipopolysaccharide (LPS, from Escherichia coli 026.B6) were purchased from Sigma (St Louis, MO, USA) and dissolved in clinical pyrogen-free $\mathrm{H}_{2} \mathrm{O}$. Levels of endotoxin in HSPG and HS stocks were measured by ETOXATE (Limulus Amebocyte Lysate, LAL) kit purchased from Sigma (St Louis, MO, USA).

\section{Preparation of Microglial Cultures}

Mice were obtained from Charles River Laboratories, Inc. (Wilmington, MA, USA) and were used according to institutional guidelines that are in compliance with national (D.I. no. 116, G.U. suppl. 40, Feb. 18, 1992, Circolare No.8, G.U., 14 Luglio 1994) and international law and policies (EEC Council Directive 86/609, OJ L358, 1 Dec. 12, 1987; Guide for the Care and Use of Laboratory Animals, U.S. National Research Council, 1996). Primary murine microglial cultures were prepared as previously described [20]. Briefly, cerebral cortical cells from day 1 old mice were dissociated with $0.25 \%$ trypsin and $0.1 \%$ DNAse (Sigma) and plated in $75 \mathrm{~cm}^{2}$ culture flasks (Corning, Acton, MA) in Dulbecco's Modified Eagle's Medium (DMEM) (Invitrogen Corporation Grand Island, NY, USA) containing 10\% heat-inactivated FBS (Invitrogen Corporation Grand Island, NY, USA) and $100 \mu \mathrm{g} / \mathrm{ml}$ gentamicin (Invitrogen Corporation Grand Island, NY, USA). Dissociated glial cultures were maintained at $37^{\circ} \mathrm{C}$ with $5 \% \mathrm{CO}_{2}$ and medium was replenished 4 days after plating. On day twelve of culture, flasks were shaken for 2 hours. The culture media supernatants (containing predominantly microglia and oligodendrocytes) were then collected and the cells were plated in either 96-well tissue plates (Nunc, Roskild, DK) at a concentration of $4 \times 10^{4}$ cells per $100 \mu \mathrm{l}$ per well, or in 48-well tissue plates at a concentration of $25 \times 10^{4}$ per $500 \mu \mathrm{l}$ per well, and maintained at $37^{\circ} \mathrm{C}$ with $5 \% \mathrm{CO}_{2}$ for 1 hour. Loosely adherent oligodendrocytes were then removed from the cultures by gentle shaking of the culture plates by hand. After pouring off the culture media supernatants (containing oligodendrocytes), the adherent microglia were maintained at $37^{\circ} \mathrm{C}$ with $5 \% \mathrm{CO}_{2}$ for subsequent treatment. The purity of microglial cultures was routinely assessed by staining with the F4/80-antibody (Serotec, Oxford, UK), which recognizes a glycoprotein expressed predominantly in microglia/macrophages cells [21], and found to be in the range of $96-98 \%$ in all cell preparations.

\section{Exposure of microglia to HSPG}

Microglial cells were incubated with HSPG at a concentration of 5, 15, 30, $40 \mu \mathrm{g} / \mathrm{ml}$ for 2, 4, 12, 24 and $48 \mathrm{~h}$. After the indicated times, culture supernatants were harvested, and frozen at $-70^{\circ} \mathrm{C}$ until assayed for levels of secreted TNF- $\alpha$ and nitrite $\left(\mathrm{NO}_{2}^{-}\right)$. After $4 \mathrm{~h}$ total RNA for each conditions was isolated from cells plated in 48-well tissue culture plates, using the TRIzol reagent protocol (Invitrogen; Carlsbad, CA, USA). In some experiments cells were exposed to $15 \mu \mathrm{g} / \mathrm{ml}$ of HS or HSPG denaturated at $90^{\circ} \mathrm{C}$ for $10 \mathrm{~min}$. After treatment at indicated times, culture media supernatants were assayed for $\mathrm{NO}_{2}$-accumulation and TNF- $\alpha$ release as described below. 
Table I: Oligonucleotide Primers Used for cDNA amplification

\begin{tabular}{cclclc}
\hline Probe & Cycles & Orientation & Tann & Sequence & Length of PCR Fragments (bP) \\
\hline GAPDH & 20 & $\begin{array}{l}\text { sense } \\
\text { antisense }\end{array}$ & 68 & $\begin{array}{l}\text { 5'TGAAGGTCGGTGTGAACGGATTTGGC3' } \\
\text { 5'CATGTAGGCCATGAGGTCCACCAC3' }\end{array}$ & 983 \\
iNOS & 26 & $\begin{array}{l}\text { sense } \\
\text { antisense } \\
\text { sense } \\
\text { antisense }\end{array}$ & 68 & $\begin{array}{l}\text { 5'CCCTTCCGAAGTTCTGGCAGCAGC3' } \\
\text { 5'GGCTGTCAGAGCCTCGTGGCTTTGG' }\end{array}$ & 493 \\
TNF $\alpha$ & 24 & & $\begin{array}{l}\text { 5'TTCTGTCTACTGAACTTCGGGTGATCGGTCC3' } \\
\text { 5'GTATGAGATAGCAAATCGGCTGACGGTGTGGG3' }\end{array}$ & 378 \\
\hline
\end{tabular}

\section{TNF- $\alpha$ assay}

Antigenic mouse TNF- $\alpha$ was detected by ELISA system from Biosurce (Camarillo, CA, USA), and based on the quantitative "sandwich" enzyme immunoassay technique. The sensitivity of the assay was $10 \mathrm{pg} / \mathrm{ml}$.

\section{Nitrite assay}

Nitrite $\left(\mathrm{NO}_{2}^{-}\right)$is a stable end-product used extensively as an indicator of NO production by cultured cells. In our experimental conditions, $\mathrm{NO}_{2}^{-}$accumulation was assayed by the Griess reaction, according to the method previously described [22]. Briefly, culture media supernatants were mixed with equal amounts of Griess reagent (p-aminobenzene sulfonamide 1\%, naphtylethylenediamide $0.1 \%$ in phosphoric acid $2.5 \%$ ) in 96 -well plates: samples were incubated at room temperature for $10 \mathrm{~min}$, and subsequently absorbance was read at $540 \mathrm{~nm}$ using a microplate reader. $\mathrm{NO}_{2}^{-}$concentrations were calculated in accordance with a sodium nitrite standard curve.

\section{RT-PCR}

One $\mu$ g total RNA quantitated spectrophotometrically and isolated from each condition was reverse transcribed using oligo(dT) $)_{20}$-primers and Superscript II-Reverse Transcriptase according to the manifacturer's protocol (Invitrogen, Carlsbad, CA, USA). c-DNA equivalent to 20 ng of total RNA was subjected to subsequent PCR analysis in a total volume of $30 \mu \mathrm{l}$ containing $25 \mathrm{pmol}$ of primers specific for TNF- $\alpha$, iNOS and glyceraldehyde phosphate dehydrogenase (GAPDH; used as an internal control) (Table I), $10 \mathrm{mM}$ Tris- $\mathrm{HCl} \mathrm{pH} 8.3$ (at $25^{\circ} \mathrm{C}$ ), $50 \mathrm{mM} \mathrm{KCl}$, $10 \%$ DMSO, $1.25 \mathrm{mM} \mathrm{MgCl}_{2}, 250 \mu \mathrm{M}$ each of dATP, dCTP, dGTP, dTTP, and 1.5 units AmpliTaq DNApolymerase (Roche, Branchburg, NJ, USA). PCR was performed at the following conditions: (1) $2 \mathrm{~min}$ at $93^{\circ} \mathrm{C}$; (2) $30 \mathrm{sec}$ at $93^{\circ} \mathrm{C}, 30 \mathrm{sec}$ at $60^{\circ} \mathrm{C}(\mathrm{TNF}-\alpha)$ or at $68^{\circ} \mathrm{C}$ (iNOS and GAPDH), $45 \mathrm{sec}$ at $72^{\circ} \mathrm{C}$ for 26 cycles (iNOS), 24 cycles (TNF- $\alpha$ ) or 20 cycles (GAPDH); (3) $10 \mathrm{~min}$. at $72{ }^{\circ} \mathrm{C}$. PCR products were analysed on $1.5 \%$ agarose gel containing $10 \mu \mathrm{g} / \mathrm{ml}$ ethidium bromide. Controls included RNA subjected to the RT-PCR procedure without addition of reverse transcriptase and PCR performed in the absence of c-DNA which always yelded negative results.

\section{Statistical analysis}

Data are expressed as means \pm standard deviations (SD). Statistical evaluation was performed by repeated measures ANOVA (analysis of variance) followed by Dunnet's test for specific comparisons. Statistical significance was set at $P<0.05$.

\section{Results \\ I. HSPG triggers production of $\mathrm{NO}_{2}^{-}$and TNF- $\alpha$ in cultured microglia}

To test whether the interaction of HSPG with microglia could induce the production of proinflammatory and potentially cytotoxic mediators, we assayed the accumulation of $\mathrm{NO}_{2}^{-}$as an indirect measure of $\mathrm{NO}$ production from mouse primary microglia stimulated with HSPG and, for comparison, with LPS. As shown in Fig. 1, microglia in resting conditions did not release detectable $\mathrm{NO}_{2}{ }^{-}$ even after a 48-h incubation, whereas HSPG induced significant accumulation of $\mathrm{NO}_{2}^{-}$in culture media supernatants in the range of that observed with LPS. The effect of HSPG on $\mathrm{NO}_{2}$ - production was time and concentration-dependent, with maximal accumulation observed at $48 \mathrm{~h}(7.5 . \pm 0.5$-fold increase over control at $30 \mu \mathrm{g} / \mathrm{ml}$ HSPG; $\mathrm{P}<0.05, \mathrm{n}=9$ ) (Fig. 1A) and production already significantly increased after a $24 \mathrm{~h}$ exposure to $15 \mu \mathrm{g} / \mathrm{ml}$ (5.2 \pm 0.4-fold increase over control; $\mathrm{P}<0.05, \mathrm{n}=9$ ) (Fig. $1 \mathrm{~B})$. We also investigated whether or not HSPG was able to induce the production of TNF- $\alpha$ by microglia. Untreated cells constitutively produced very small amounts of TNF- $\alpha$, whereas their stimulation with HSPG or LPS resulted in the release of significant levels of TNF$\alpha$, with maximal accumulation observed at $4 \mathrm{~h}(25 \pm 1.8$ fold increase over control; $\mathrm{P}<0.05, \mathrm{n}=9$ ), followed by a decrease at later times (Fig. 2A). Concentration-response studies demonstrated that the amount of TNF- $\alpha$ released into the culture media supernatants increased with increasing concentrations of HSPG (Fig. 2B). TNF- $\alpha$ release was already significantly increased after a $24 \mathrm{~h}$ exposure to $15 \mu \mathrm{g} / \mathrm{ml}$ HSPG (11.6 \pm 0.85.-fold increase over control; $\mathrm{P}<0.05, \mathrm{n}=9$ ). Specificity of the effects of 

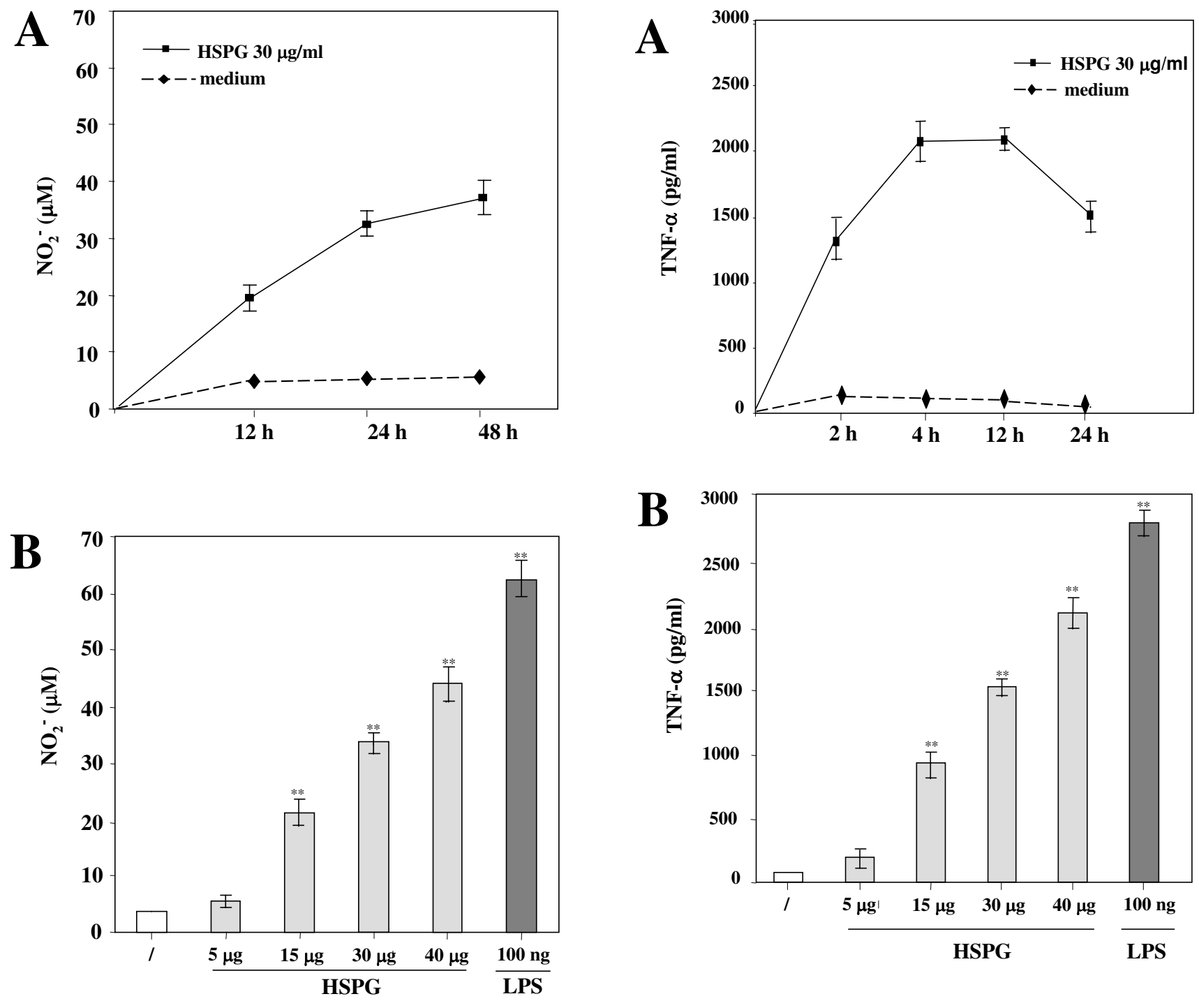

Figure I

Effect of HSPG on the accumulation of $\mathrm{NO}_{2}{ }^{-}$from murine microglia. In panel $\mathbf{A}$, time course of $\mathrm{NO}_{2}^{-}$production by murine microglia in response to HSPG. Microglial cells were cultured in 96-well plates and stimulated with 30 $\mu \mathrm{g} / \mathrm{ml}$ HSPG for up to $48 \mathrm{~h}$. In panel B, dose-dependent effect of HSPG on the accumulation of $\mathrm{NO}_{2}$ - by murine microglia. Microglial cells were cultured in 96-well plates and stimulated for $24 \mathrm{~h}$ with increasing concentrations of HSPG, or $100 \mathrm{ng} / \mathrm{ml}$ LPS. Mean values \pm SD of assays performed with culture media supernatants collected and pooled from triplicate wells for each condition are shown $(n=9)$. Both panels depict a representative experiment out of three performed with similar results. $*^{*} \mathrm{p}<0.01$.

\section{Figure 2}

Effect of HSPG on TNF- $\alpha$ release by murine microglia. In panel A, time course of TNF- $\alpha$ production by murine microglia in response to HSPG. Microglial cells were cultured in 96-well plates and stimulated with $30 \mu \mathrm{g} / \mathrm{ml} \mathrm{HSPG}$ for up to $24 \mathrm{~h}$. In panel B, dose-dependent effect of HSPG on the accumulation of TNF- $\alpha$ by murine microglia. Microglial cells were cultured in 96-well plates and stimulated for $24 \mathrm{~h}$ with increasing concentrations of HSPG or $100 \mathrm{ng} / \mathrm{ml}$ LPS. Mean values \pm SD of assays performed with culture media supernatants collected and pooled from triplicate wells for each condition are shown $(n=9)$. Both panels depict a representative experiment out of three performed with similar results. ${ }^{* *} \mathrm{p}<0.01$. 


\section{/ LPS HSPG}
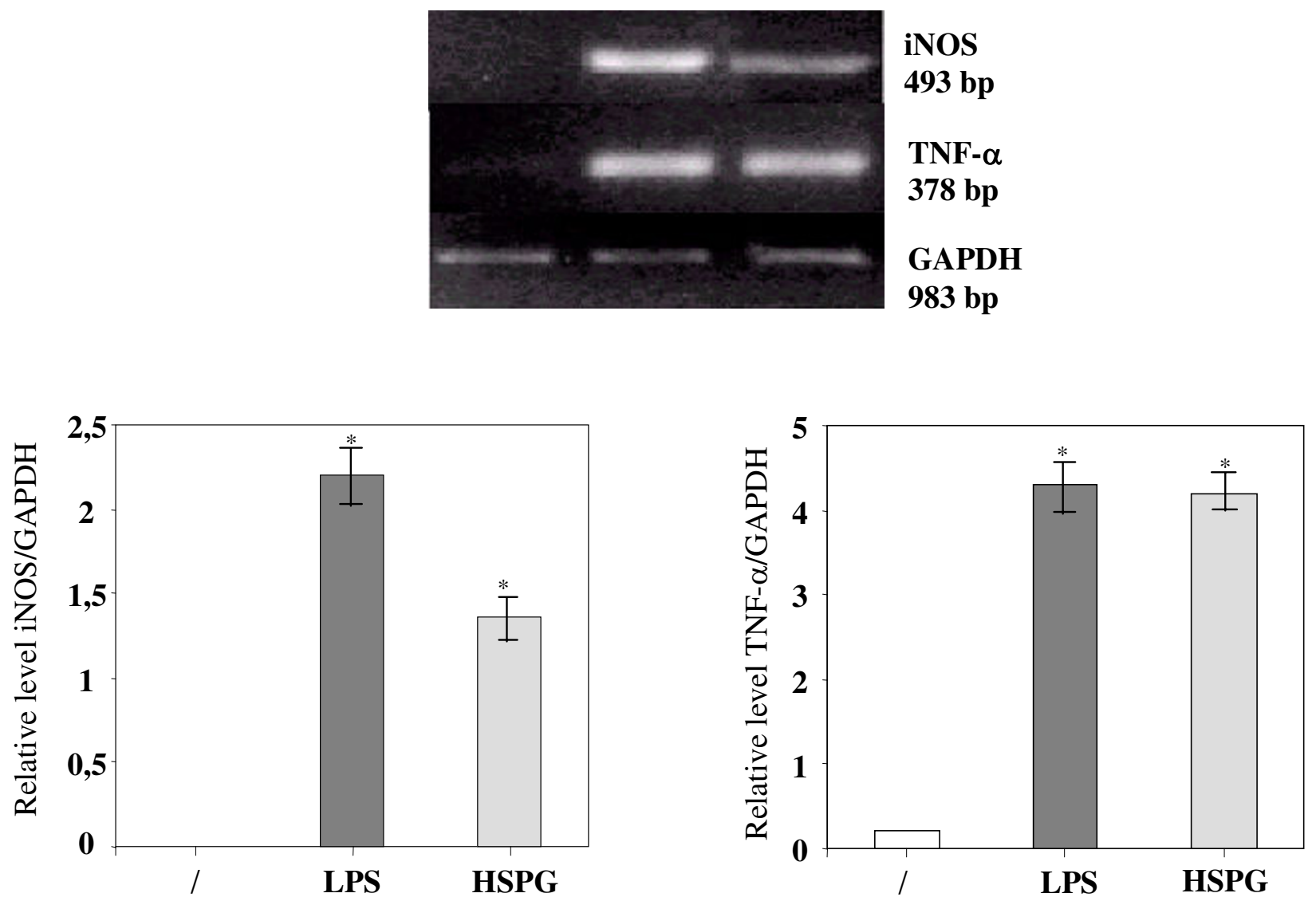

Figure 3

Effect of HSPG on iNOS and TNF- $\alpha$ mRNA expression in murine microglia. One-day-old microglial cells were cultured in 48-well plates and then stimulated for 4 hours with $15 \mu \mathrm{g} / \mathrm{ml} \mathrm{HSPG}$ or $100 \mathrm{ng} / \mathrm{ml}$ LPS. Total RNA was extracted and analysed by RT-PCR. The densitometric evaluation of the bands obtained from three independent experiments in duplicates are reported $(n=6)$; values are expressed as the relative level of iNOS/GAPDH and TNF $\alpha / G A P D H .{ }^{*} p<0.05$.

HSPG on microglial activation was confirmed by LAL test that excluded trace levels of endotoxin in our HSPG stocks.

\section{HSPG induces expression of iNOS and TNF- $\alpha$ mRNA in cultured microglia}

To determine whether the production of $\mathrm{NO}_{2}-$ and TNF- $\alpha$ triggered by HSPG reflected induction of iNOS and TNF$\alpha$ mRNA, RT-PCR analysis was performed on microglia total RNA, using probes complementary to the mouse macrophage iNOS and TNF- $\alpha$ coding sequences. In resting conditions the mRNA expression for iNOS and TNF- $\alpha$ in microglia was absent. On the contrary, mRNA levels for iNOS and TNF- $\alpha$ were clearly induced after stimulation of the cells for $4 \mathrm{~h}$ with HSPG at the concentration of $15 \mu \mathrm{g} /$ $\mathrm{ml}$ or $100 \mathrm{ng} / \mathrm{ml} \mathrm{LPS} \mathrm{(Fig.} \mathrm{3).}$

\section{Microglial activation induced by HSPG is mediated primarily by the protein core}

To examine whether the protein core or the GAGs of HSPG were involved in mediating microglial activation, the effects of HSPG were compared with those obtained using $\mathrm{HSPG}$ denaturated at $90^{\circ} \mathrm{C}$ for $10 \mathrm{~min}$ (HSPG-hd) or HS-GAG chains (HS). As shown in Fig. 4, exposure of microglia to $30 \mu \mathrm{g} / \mathrm{ml}$ HSPG-hd almost completely abolished the production of $\mathrm{NO}_{2}{ }^{-}(1 \pm 0.2 \mu \mathrm{M} ; \mathrm{P}<0.05, \mathrm{n}=9)$ and particularly of TNF- $\alpha(98 \pm 10 \mathrm{pg} / \mathrm{ml} ; \mathrm{n}=9)$. Stimulation with $30 \mu \mathrm{g} / \mathrm{ml}$ HS only slightly affected release of TNF- $\alpha(200 \pm 18 \mathrm{pg} / \mathrm{ml} ; \mathrm{P}<0.05, \mathrm{n}=9)$ but not 

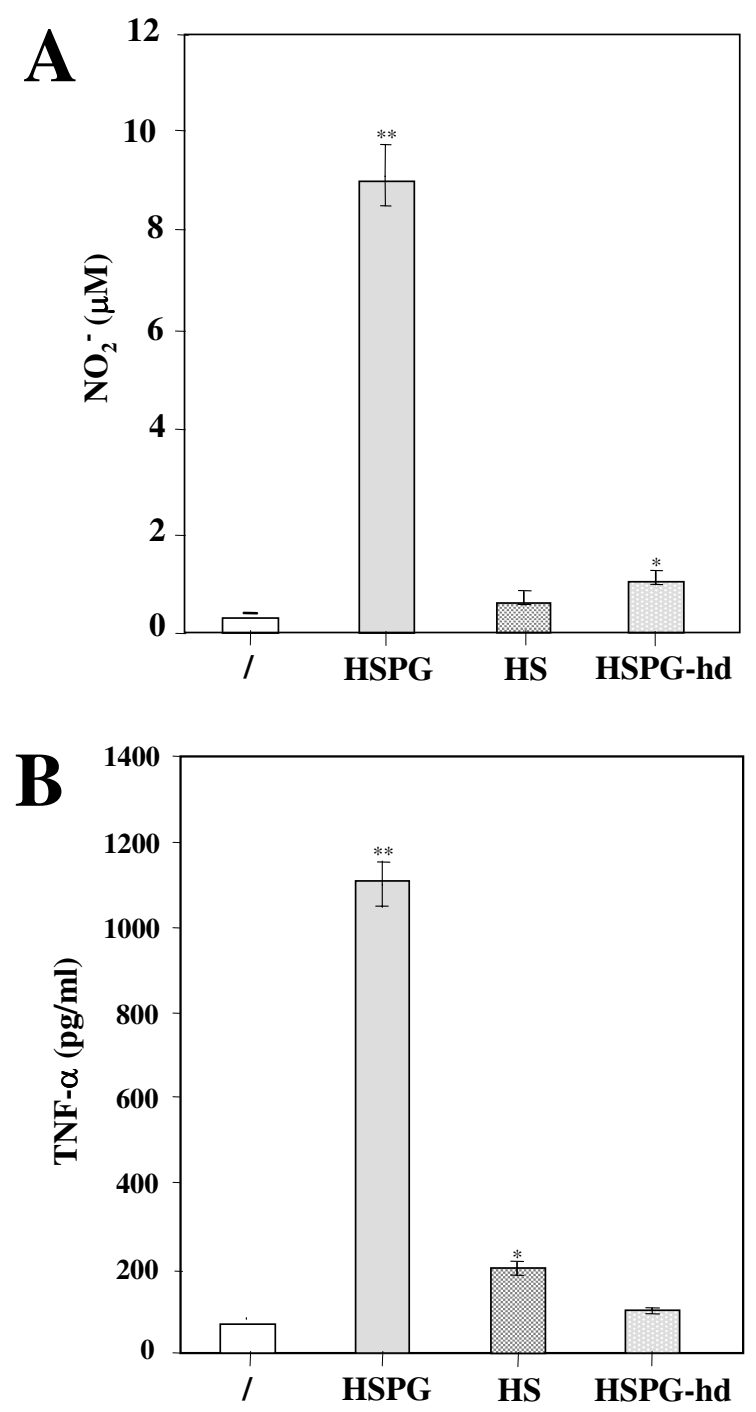

Figure 4

Effect of heat denaturated HSPG and HS-GAG chains on $\mathrm{NO}_{2}^{-}$and TNF- $\alpha$ release by murine microglia. Microglial cells were cultured in 96-well plates and stimulated with $15 \mu \mathrm{g} / \mathrm{ml}$ HSPG, I $5 \mu \mathrm{g} / \mathrm{ml}$ heat denaturated HSPG (HSPG-hd) or $15 \mu \mathrm{g} / \mathrm{ml}$ HS-GAG chains (HS). After 24 $h$, culture media supernatants were assayed for $\mathrm{NO}_{2}^{-}$accumulation $(\mathbf{A})$ and TNF- $\alpha$ release $(\mathbf{B})$. Mean values \pm SD of assays performed with culture media supernatants collected and pooled from triplicate wells for each condition are shown $(n=9)$. Both panels depict a representative experiment out of three performed with similar results. ${ }^{*} p<0.05$, **p $<0.01$.

accumulation of $\mathrm{NO}_{2}^{-}(0.8 \pm 0.1 \mu \mathrm{M} ; \mathrm{n}=9)$. The lack of ability of HSPG-hd and HS to maintain $\mathrm{NO}_{2}^{-}$accumulation and TNF- $\alpha$ release appeared to be mediated at the transcriptional level since HSPG-hd and HS failed to increase both iNOS and TNF- $\alpha$ mRNA transcription (Fig. 5).

\section{Discussion}

The identification in senile plaques of pathologic stimuli that can lead to microglial activation represents one of the important issues of immunologic research in AD. Previous studies have shown that microglia upon stimulation with $A \beta$ can produce proinflammatory and cytotoxic mediators, and that these mediators play a role in the pathogenesis of $\mathrm{AD}[23-26]$. The demonstration of the indirect neuronal injury prompted us to investigate if, in addition to $A \beta$, others molecules present in senile plaques could be involved in similar mechanisms of microglial activation. We have identified HSPG as a potential candidate in this process on the basis that this molecule has been found to be associated with $\mathrm{A} \beta$ peptide-containing deposits and suggested to act as pathological chaperone, increasing $\beta$-pleated structure within $A \beta[27,28]$.

We demonstrate that HSPG is able to induce the release of $\mathrm{NO}_{2}{ }^{-}$and TNF- $\alpha$ by cultured primary murine microglia. By assessing iNOS and TNF- $\alpha$ mRNA expression with RTPCR we have also shown that the release of NO and TNF$\alpha$ in HSPG-stimulated microglial cells is due to the induction of iNOS and TNF- $\alpha$ gene expression. These findings suggest that, in addition to A $\beta$, also HSPG is able to activate microglia with production of proinflammatory molecules known to be present in the brain of $\mathrm{AD}$ patients.

The precise mechanism by which microglia mediate neuronal cell injury in AD is incompletely understood and several mediators have been proposed, among them NO and TNF- $\alpha$ [29-31]. Even though physiological levels of NO may influence synaptic efficacy by regulating neurotrasmitter release [32], excess NO may cause neuronal degeneration by combining with oxygen radicals such as superoxide anion to form the highly toxic peroxynitrite ion [33]. Similarly, TNF- $\alpha$ has been reported to be trophic to rat hippocampal neurons [34]. However, transgenic mice that overexpress TNF- $\alpha$ exibit severe inflammation and neurodegeneration [35]. Moreover, in vitro studies have shown that some $A \beta$-induced microglial activities, including neurotoxicity and chemokine production, are mediated through release of endogenous TNF- $\alpha$ $[23,36,37]$. That TNF- $\alpha$ is presumably involved in AD pathology is also supported by its elevated levels in the serum, CSF and cerebral cortex of AD patients [38,39]. In view of the information summarized above, it is conceivable that generation of NO and TNF- $\alpha$ from microglial cells is one means by which HSPG may enhance the inflammatory reaction in neuritic plaques, and thus pathogenesis of $\mathrm{AD}$. However, it must be pointed out that astrocytes represent the main source of NO in the plaques 


\section{/ LPS HSPG HS HSPG-hd}

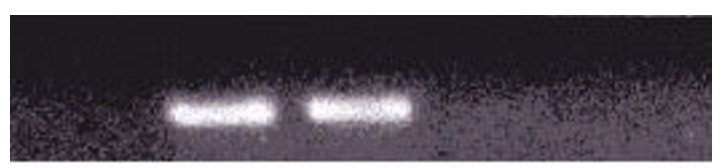

\section{iNOS}

493 bp

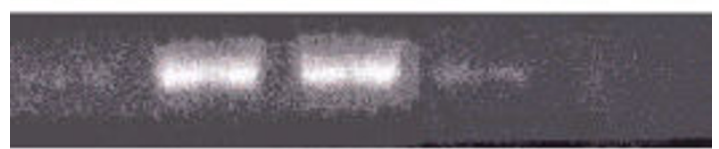

TNF- $\alpha$

378 bp

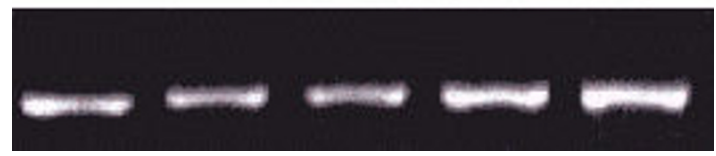

GAPDH

983 bp
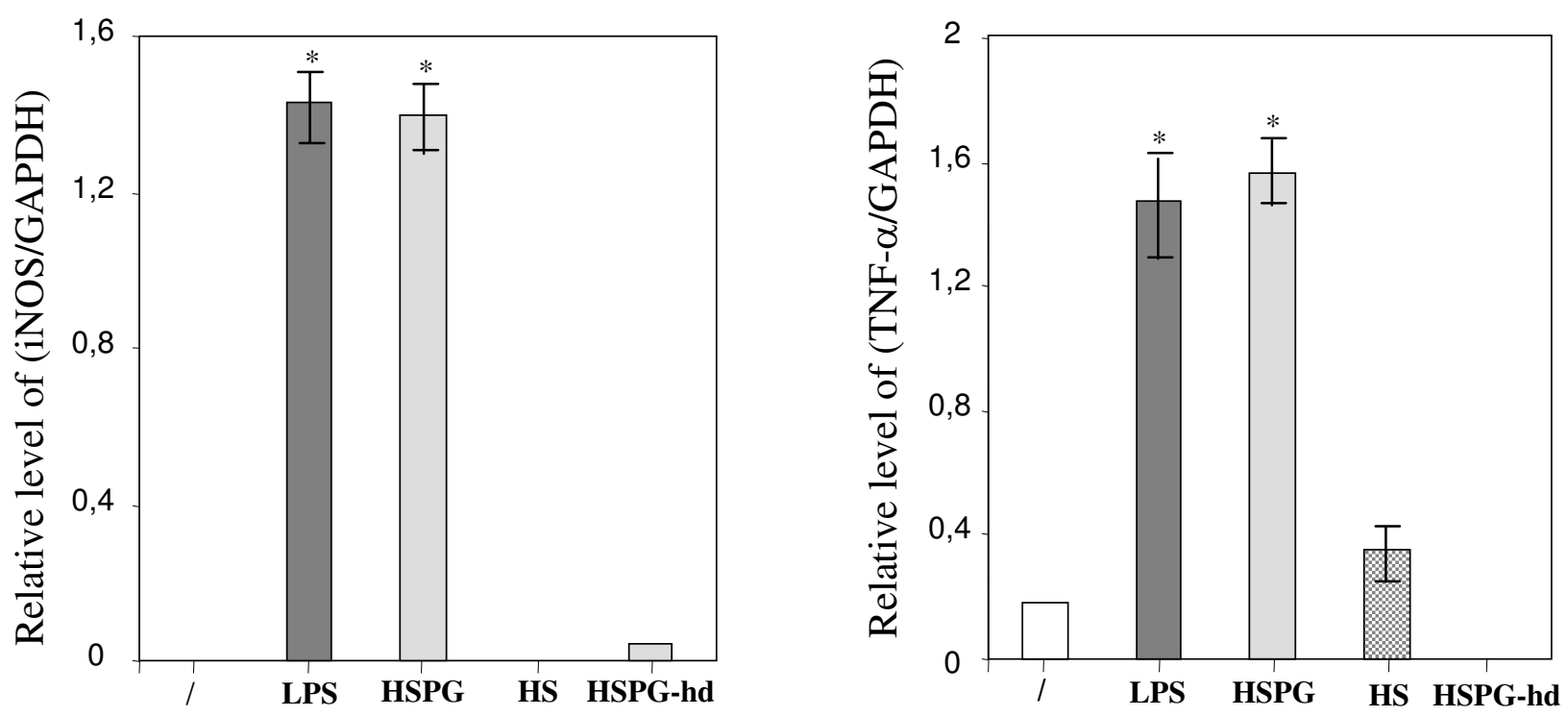

Figure 5

Effect of heat denaturated HSPG and HS-GAG chains on iNOS and TNF- $\alpha$ mRNA expression in murine microglia. Microglial cells were cultured in 48-well plates and then stimulated for 4 hours with I5 $\mu \mathrm{g} / \mathrm{ml} \mathrm{HSPG}$, I5 $\mu \mathrm{g} / \mathrm{ml}$ heat denaturated HSPG (HSPG-hd), I $5 \mu \mathrm{g} / \mathrm{ml}$ HS-GAG chains (HS) or $100 \mathrm{ng} / \mathrm{ml}$ LPS. Total RNA was extracted and analysed by RT$P C R$. The densitometric evaluation of the bands obtained from three independent experiments in duplicates are reported $(\mathrm{n}=$ 6); values are expressed as the relative level of iNOS/GAPDH and TNF- $\alpha / G A P D H . *^{*}<0.05$.

whereas release of neurotoxic levels of NO by microglia has been shown in vitro $[40,23,24,41]$. Future studies will be needed in order to determine whether HSPG also activates astrocytes to produce NO and TNF- $\alpha$.

The lack of inflammation and microglial activation described in diffuse plaques opens the question about the actual proinflammatory role played by HSPG at early stages of plaque evolution. Our results show that activa- tion of microglial cells by HSPG is concentration-dependent, both in terms of $\mathrm{NO}_{2}{ }^{-}$accumulation and TNF- $\alpha$ release in the culture medium, and that $15 \mu \mathrm{g} / \mathrm{ml}$ of the compound is sufficient to trigger the activation process. Although HSPG has been immunohistologically localized to senile plaques its biochemical isolation from these structures, and thus its quantification, have yet to be performed [42]. Thus, we cannot establish at present whether the threshold for microglial activation we found can 
explain the discrepancies in immunohistochemical localization of HSPG in diffuse plaques lacking inflammation.

The cellular source of HSPG in mammalian brain is represented by microglia and astrocytes which have been shown by immunofluorescence and/or western blotting to express HSPG both in vitro and in vivo $[43,44]$. Nevertheless, the factors implicated in HSPG biosynthesis and deposition have been poorly investigated. Recently regulation of HSPG by injury and IL- $1 \alpha$ has been demonstrated in astrocytes and microglia [45]. Therefore, the stimulation of microglial cells by HSPG, followed by increased production of proinflammatory cytokines could stimulate further HSPG formation in an autocrine, feedforward manner.

The importance of HSPG deposition in AD pathogenesis is supported by the fact that HSPG binds $A \beta$, accelerates $\mathrm{A} \beta$ fibril formation and maintains $\mathrm{A} \beta$ fibril stability [46]. Most of these effects of HSPG have been shown to be due to its associated HSGAG side-chains, as also suggested by the lack of extracellular $A \beta$ deposits in transgenic mice overexpressing HSPG protein core [47]. This contrasts with our results showing that the proinflammatory role of HSPG is primarily mediated by its protein core. However, in these transgenic mice HSPG was detected only inside the cells, i.e. without accumulation of the compound in the extracellular environment, which instead is a hallmark of AD neurodegeneration. Studies in these animals, therefore, do not allow drawing conclusions about the role of extracellular HSPG in AD.

In conclusion, the potential participation of HSPG in NO and TNF- $\alpha$-mediated neuronal injury induced by microglia adds a novel biological role of this molecule in the pathogenesis of $\mathrm{AD}$. These data indicate that HSPG plays an immunomodulatory role in the activation of microglia, in addition to that proposed in amyloidogenic pathways and demonstrate another mechanism by which immune responses may be triggered in $\mathrm{AD}$ brain. Therefore, a further understanding of the role of HSPG in the pathogenesis of $\mathrm{AD}$ would assist in the development of rational, targeted therapeutic strategies to combat this neurodegenerative disorder.

\section{Acknowledgements}

We are grateful to financial support from the MANAD project of the European Community and from "Ricerca Finalizzata Alzheimer 2000" of the Italian Ministery of Health.

\section{References}

I. Neuroinflammation Working Group: Inflammation and Alzheimer's disease. Neurobiol Aging 2000, 21:383-42I.

2. Meda L, Baron P, Scarlato G: Glial activation in Alzheimers disease: the role of $A \beta$ and its associated proteins. Neurobiol Aging 200I, 22:885-893.

3. Goldgaber D, Lerman MI, McBride OW, Saffioti U, Gajdusek DC: Characterization and chromosomal localization of a cDNA encoding brain amyloid of Alzheimer's disease. Science 1987, 235:877-880.

4. Kang J, Lemaire HG, Unterbeck A, Salbaum JM, Masters CL, Grzeschik KH, Multhaup G, Beyreuther K, Muller-Hill B: The precursor of Alzheimer's disease amyloid A4 protein resembles a cellsurface receptor. Nature 1987, 325:733-736.

5. Roher A, Wolfe D, Palutke M, Kukuruga D: Purification, ultrastructure, and chemical analysis of Alzheimer disease amyloid plaque core protein. Proc Natl Acad Sci USA 1986, 83:2662-2666.

6. Wisniewski T, Castano EM, Golabek A, Vogel T, Frangione B: Acceleration of Alzheimer's fibril formation by apolipoprotein $E$ in vitro. Am J Pathol 1994, I45: 1030-1035.

7. Wood SJ, Chan W, Wetzel R: Seeding of $\mathbf{A} \beta$ fibril formation is inhibited by all three isotypes of apolipoprotein E. Biochemistry 1996, 35: 12623-12628.

8. Monji A, Tashiro K, Yoshida I, Tashiro N: Laminin inhibits Abeta42 fibril formation in vitro. Brain Res 1998, 788: 187-190.

9. Alvarez A, Bronfman F, Perez CA, Vicente M, Garrido J, Inestrosa NC: Acetylcholinesterase, a senile plaque component, affects the fibrillogenesis of amyloid- $\beta$-peptide. Neurosci Lett 1995, 20I:49-52.

10. Eriksson $S$, Janciauskiene $S$, Lannfelt $L$ : $\alpha_{1}$-Antichymotrypsin regulates Alzheimer $\beta$-amyloid peptide fibril formation. Proc Natl Acad Sci USA 1995, 92:2313-2317.

II. Castillo GM, Ngo C, Cummings J, Wight TN, Snow AD: Perlecan binds to the $\beta$-amyloid proteins $(A \beta)$ of Alzheimer's disease, accelerates $A \beta$ fibril formation, and maintains $A \beta$ fibril stability. J Neurochem 1997, 69:2452-2465.

12. van Horssen J, Wesseling P, van der Heuvel L, de Waal R, Verbeek M: Heparan sulphate proteoglycans in Alzheimer's disease and amyloid-related disorders. Lancet Neurol 2003, 2:482-492.

13. Snow AD, Wight TN: Proteoglycans in the pathogenesis of Alzheimer's disease. Neurobiol Aging 1989, 10:48I-497.

14. Snow AD, Mar H, Nochlin D, Sekiguchi RT, Kimata K, Koike Y, Wight TN: Early accumulation of heparan sulfate in neurons and in the beta-amyloid protein containing lesions of Alzheimer's disease and Down's syndrome. Am J Pathol 1990, 137: I 253- 270.

15. Snow AD, Sekiguchi RT, Nochlin D, Kalaria RN, Kimata K: Heparan sulfate proteoglycan in diffuse plaques of hippocampus but not in cerebellum of Alzheimer's disease brain. Am J Pathol 1994, 144:337-347.

16. Buée L, Ding W, Delacourte A, Fillit $\mathrm{H}$ : Binding of secreted human neuroblastoma proteoglycans to the Alzheimer's amyloid A4 peptide. Brain Res 1993, 60 I:154-163.

17. Snow AD, Kinsella MG, Parks E, Sekiguchi RT, Miller JD, Kimata K, Wight TN: Differential binding of vascular cell-derived proteoglycans (perlecan, biglycan, decorin, and versican) to the beta-amyloid protein of Alzheimer's disease. Arch Biochem Biophys 1995, 320:84-95.

18. Narindrasorasak S, Lowry DE, Gonzalez-DeWhitt PA, Poorman RA, Greenberg BD, Kisilevsky R: High affinity interactions between the Alzheimer's beta-amyloid precursor proteins and the basement membrane form of heparan sulfate proteoglycan. J Biol Chem I991, 266:12878-12883.

19. Gumpta-Bansal R, Frederickson CA, Brunden KR: Proteoglycanmediated inhibition of A $\beta$ proteolysis. J Biol Chem 1995, 270:18666-1867I.

20. Agresti C, Aloisi F, Levi G: Heterotypic and homotypic cellular interactions influencing the growth and differentiation of biopotential oligodendrocytes-type-2 astrocytes progenitors in cultures. Dev Biol 1991, I 14:16-29.

21. Lawson L, Perry V, Dri P, Gordon S: Heterogeneity in the distribution and morphology of microglia in the normal adult mouse brain. Neuroscience 1990, 39:151-170.

22. Rockett KA, Awburn MM, Aggarwal BB, Cowden WB, Clark IA: In vivo induction of nitrite and nitrate by tumor necrosis factor, lymphotoxin, and interleukin-I: possible roles in malaria. Infect Immun 1991, 60:3725-3730.

23. Meda L, Cassatella MA, Szendrei G, Otvos L, Baron P, Villalba M, Ferrari D, Rossi F: Activation of microglial cells by $\beta$-amyloid protein and IFN- $\gamma$. Nature 1995, 374:647-650.

24. Goodwin JL, Uemura E, Cunnick JE: Microglial release of nitric oxide by synergistic action of $\beta$-amyloid and IFN $\gamma$. Brain Res 1995, 692:207-2।4. 
25. London JA, Biegel D, Pachter JS: Neurocytopathic effects of $\beta$ amyloid-stimulated monocytes: a potential mechanism for central nervous system damage in Alzheimer's disease. Proc Natl Acad Sci USA 1996, 93:4I47-4I 52.

26. Meda L, Baron P, Prat E, Scarpini E, Scarlato G, Cassatella MA, Rossi F: Proinflammatory profile of cytokine production by human monocytes and murine microglia stimulated with $\beta$-amyloid(25-35). J Neuroimmunol 1999, 93:45-52.

27. Kisilewsky R, Snow A: The potential significance of sulphated glycosaminoglycans as a common constituents of all amyloids: or, perhaps amyloid is not a misnomer. Med Hypothesis 1988, 26:231-236.

28. Wisniewski T, Frangione B: Molecular biology of Alzheimer's amyloid-Dutch variant. Mol Neurobiol 1992, 6:75-86.

29. Eikelenboom P, Zhan SS, vanGool WA, Allsop D: Inflammatory mechanisms in Alzheimer's disease. Trends Pharmacol Sci 1994, 15:447-450.

30. Rogers J: Infammation as a pathogenic mechanism in Alzheimer's disease. Arzneimittelforschung 1995, 45:439-442.

31. McGeer PL, Schulzer M, McGeer EG: Arthritis and anti-inflammatory agents as possible protective factors for Alzheimer's disease. Neurology 1996, 47:425-432.

32. Brenman JE, Bredt DS: Synaptic signalling by nitric oxide. Curr Opin Neurobiol 1997, 7:374-378.

33. Smith MA, Rickey HP, Sayre LM, Beckman JS, Perry G: Widespread peroxynitrite-mediated damage in Alzheimer's disease. J Neurosci 1997, 17:2653-2657.

34. Barger SW, Horster D, Furukawa K, Goodman Y, Krieglstein J, Mattson MP: TNFs alpha, and beta protect neurons against amyloid beta-peptide toxicity: evidence for involvement of a kappa B-binding factor, and attenuation of peroxide, and Ca+ accumulation. Proc Natl Acad Sci USA 1995, 92:328-332.

35. Akassoglou K, Probert L, Kontogeorgos G, Kollias G: Astrocytespecific but not neuron-specific transmembrane TNF triggers inflammation and degeneration in the central nervous system of transgenic mice. J Immunol 1997, 158:438-445.

36. Meda L, Bernasconi S, Bonaiuto C, Sozzani S, Zhou D, Otvos L, Mantovani $A$, Rossi $F$, Cassatella MA: $\beta$-amyloid (25-35) peptide and IFN $\gamma$ synergistically induce the production of the chemotactic cytokine MCP-I/JE in monocytes, and microglial cells. Immunol 1996, 157:1213-1218.

37. Shalit F, Sredni B, Rosenblatt-Bin H, Kazimirsky G, Brodie C, Huberman M: Beta-amyloid peptide induces TNF $\alpha$ and nitric oxide production in murine macrophages cultures. Neuroreport 1997, 8:3577-3580.

38. Fillit $H$, Ding WH, Buee L, Kalman J, Altstiel L, Lawlor B, Wolf-Klein G: Elevated circulating TNF levels in Alzheimer's disease. Neurosci Lett 199I, I 29:318-320.

39. Tarkowski E, Blennow K, Wallin A, Tarkowski A: Intracerebral production of TNF- $\alpha$, a local neuroprotective agent, in Alzheimer's disease and vascular dementia. J Clin Immunol 1999, 19:223-230.

40. Wallace MN, Geddes JG, Farquhar DA, Masson MR: Nitric oxide synthase in reactive astrocytes adjacent to $\beta$-amyloid plaques. Exp Neurol 1997, I44:266-272

4I. Masayuki I, Sunamoto M, Ohnishi K, Ichimori Y: $\beta$-amyloid proteindependent nitric oxide production from microglial cells and neurotoxicity. Brain Res 1996, 720:93-100.

42. Snow AD, Mar H, Nochlin D, Kimata K, Kato M, Suzuki S, Hassell J, Wight TN: The presence of heparan sulfate proteoglycans in the neuritic plaques and congophilic angiopathy of Alzheimer's disease. Am J Pathol 1988, 1 33:456-463.

43. Su JH, Cummings BJ, Cotman CW: Localization of heparan sulfate glycosaminoglycan and proteoglycan core protein in aged brain and Alzheimer's disease. Neuroscience 1992 , $51: 80|-8| 3$.

44. Miller JD, Cummings J, Maresh GA, Walker DG, Castillo GM, Ngo C, Kimata K, Kinsella MG, Wight TN, Snow AD: Localization of perlecan (or perlecan-related macromolecule) to isolated microglia in vitro and to microglia/macrophages following infusion of beta-amyloid protein into rodent hippocampus. Glia 1997, 21:228-243.

45. Garcia de Yebenez EG, Ho A, Damani T, Fillit H, Blum M: Regulation of the heparan sulfate proteoglycan, perlecan, by injury and interleukin-I $\alpha$. J Neurochem 1999, 73:8I2-820.
46. Castillo GM, Cummings JA, Ngo C, Yang W, Snow AD: Novel purification and detailed characterization of perlecan isolated from the Engelbreth-Holm-Swarm tumor for use in an animal model of fibrillar $A \beta$ amyloid persistence in brain. Biochem 1996, I 20:433-444.

47. Hart M, Li L, Tokunaga T, Lindsey R, Hassell JR, Snow AD, Fukuchi K: Overproduction of perlecan core protein in cultured cells and transgenic mice. J Pathol 200I, 194:262-269.
Publish with Biomed Central and every scientist can read your work free of charge

"BioMed Central will be the most significant development for disseminating the results of biomedical research in our lifetime. "

Sir Paul Nurse, Cancer Research UK

Your research papers will be:

- available free of charge to the entire biomedical community

- peer reviewed and published immediately upon acceptance

- cited in PubMed and archived on PubMed Central

- yours - you keep the copyright 